University of South Florida

DIGITAL COMMONS

Digital Commons @ University of

@ UNIVERSITY OF SOUTH FLORIDA

South Florida

School of Geosciences Faculty and Staff

Publications

School of Geosciences

2005

\title{
The 2003 Boumerdes, Algeria Earthquake: Regional Moment Tensor Analysis
}

Jochen Braunmiller

Swiss Seismological Service, jbraunmiller@usf.edu

Fabrizio Bernardi

Swiss Seismological Service

Follow this and additional works at: https://digitalcommons.usf.edu/geo_facpub

Part of the Earth Sciences Commons

\section{Scholar Commons Citation}

Braunmiller, Jochen and Bernardi, Fabrizio, "The 2003 Boumerdes, Algeria Earthquake: Regional Moment Tensor Analysis" (2005). School of Geosciences Faculty and Staff Publications. 810.

https://digitalcommons.usf.edu/geo_facpub/810

This Article is brought to you for free and open access by the School of Geosciences at Digital Commons @ University of South Florida. It has been accepted for inclusion in School of Geosciences Faculty and Staff Publications by an authorized administrator of Digital Commons @ University of South Florida. For more information, please contact digitalcommons@usf.edu. 


\title{
The 2003 Boumerdes, Algeria earthquake: Regional moment tensor analysis
}

\author{
Jochen Braunmiller and Fabrizio Bernardi \\ Swiss Seismological Service, Institute of Geophysics, Eidgenössische Technische Hochschule Zürich, Zurich, Switzerland
}

Received 19 November 2004; revised 10 February 2005; accepted 18 February 2005; published 18 March 2005.

[1] We used regional broadband seismograms to determine seismic moment tensors for the destructive May 21, 2003 Boumerdes (Algeria) $\mathrm{M}_{\mathrm{w}}=7.0$ earthquake and its larger aftershocks. Fully automatic inversions using near-real time data provided solutions for seven $\mathrm{M}_{\mathrm{w}} \geq 4.7$ events within 90 minutes after event occurrence. After adding offline data, we manually obtained 30 solutions $\left(\mathrm{M}_{\mathrm{w}} \geq 3.8\right)$ from May 2003 to January 2004. All have shallow source depths $(6-21 \mathrm{~km})$. The median $\mathrm{P}$-axis orientation $\left(338^{\circ}\right)$ of 24 thrust and four strike-slip events is consistent with Africa-Eurasia plate motion $\left(330^{\circ}\right)$. The main shock hypocenter at $8-10 \mathrm{~km}$ depth at the coastline and its shallow southward dip $\left(25^{\circ} \pm 5^{\circ}\right)$ puts the fault surface trace $15-20 \mathrm{~km}$ offshore, consistent with documented seafloor deformation at the base of the continental slope. A main shock rupture length of about $50 \mathrm{~km}$ is deduced from first day aftershocks and location of strike-slip events. The strike-slip events probably define the western rupture end and indicate a left-step of main convergence. Fault strike variability of thrust events suggests fault orientation changes and possibly fault segmentation. Citation: Braunmiller, J., and F. Bernardi (2005), The 2003 Boumerdes, Algeria earthquake: Regional moment tensor analysis, Geophys. Res. Lett., 32, L06305, doi:10.1029/ $2004 \mathrm{GL} 022038$.

\section{Introduction}

[2] The $\mathrm{M}_{\mathrm{w}}=7.0$ May 21, 2003 Boumerdes earthquake occurred about $50 \mathrm{~km}$ east of Algiers [Ayadi et al., 2003; Yelles-Chaouche et al., 2003]. A maximum intensity X (EMS 98) was assigned to heavily damaged coastal areas from Boumerdes to Dellys (Figure 1) where over 2000 people died due to building collapses. Along this $55 \mathrm{~km}$ long stretch, Meghraoui et al. [2004] found an average coastal uplift of $0.5 \mathrm{~m}$. Minor cracks and landslides, but no surface faulting occurred [Ayadi et al., 2003; YellesChaouche et al., 2003]. The relocated main shock hypocenter is at the coastline $\left(36.83^{\circ} \mathrm{N}, 3.65^{\circ} \mathrm{E}\right)$ at $8-10 \mathrm{~km}$ depth [Bounif et al., 2004]. Modeling of GPS [Yelles et al., 2004], uplift [Meghraoui et al., 2004], geodetic and strong motion [Semmane et al., 2005], and teleseismic, GPS and uplift data [Delouis et al., 2004] and aftershock locations [Bounif et al., 2004] suggest rupture along a 50-55 km long south-dipping thrust fault. Slip modeling [Delouis et al., 2004; Semmane et al., 2005] shows a 12-18 s rupture duration and two major slip patches with displacements up to $2.5-3 \mathrm{~m}$.
[3] Destructive earthquakes in northern Algeria are due to Africa-Eurasia convergence. Most deformation occurs along a narrow strip of NE-SW trending right-stepping folds and faults of the Tell Atlas [Meghraoui et al., 1986]. Low convergence ( $\sim 6 \mathrm{~mm} / \mathrm{yr}$, NUVEL-1A [DeMets et al., 1994]) causes infrequent, but destructive earthquakes. The largest 20th century event was the $\mathrm{M}_{\mathrm{w}}=7.31980 \mathrm{El}$ Asnam event $150 \mathrm{~km}$ southwest of Algiers. Near Boumerdes, seismicity before 2003 was considered low [YellesChaouche et al., 2003].

[4] Installation of broadband seismic stations along the Mediterranean Sea (Figure 1) allows source mechanism retrieval of moderate earthquakes using regional waveforms. We present fully automatic near-real time moment tensor (MT) solutions to illustrate rapid source parameter estimation. Combining near-real time and later available data, we obtained 30 MTs for the Boumerdes sequence. We use the solutions and their relocations to develop a rupture model and to address the fault surface trace location.

\section{Automatic Moment Tensor Analysis}

[5] Since 2000, we have been performing near-real time, fully automatic deviatoric MT inversions in the EuropeanMediterranean area [Bernardi et al., 2004]. We invert complete long-period three-component regional seismograms and find the depth by grid-search. The 50-100 s waveforms, insensitive to crustal heterogeneities, can be fitted with PREM synthetics even for slightly inaccurate locations and long paths. After automatic quality control, solutions are available 90 minutes after an event at http:// emsc-csem.org and http://www.seismo.ethz.ch/mt.

[6] We obtained solutions for seven $M_{w} \geq 4.7$ events of the Boumerdes sequence (Table 1). Their source parameters (MT, $\mathrm{M}_{\mathrm{w}}$, depth) were later confirmed by solutions from Harvard, the USGS and our manual analysis. Our automatic main shock MT (\#1 Table 1) provided the first, unsaturated size estimate $\left(\mathrm{M}_{\mathrm{w}}=6.8\right)$. Submarine slides had cut several underwater phone cables to Algeria [Hébert and Alasset, 2003] severing communication. Rapid, remotely derived size estimates, indicating destruction near the epicenter, helped initiate disaster relief efforts.

\section{Off-Line Moment Tensor Analysis}

[7] For off-line analysis, we used all broadband waveforms available within months after event occurrence. The larger three-component dataset improves azimuthal coverage and contains more close-in stations (Figure 1) than for the automatic analysis. This results in better-constrained mechanisms and permits analysis of smaller events. We filtered the data to periods with good signal-to-noise ratio. 


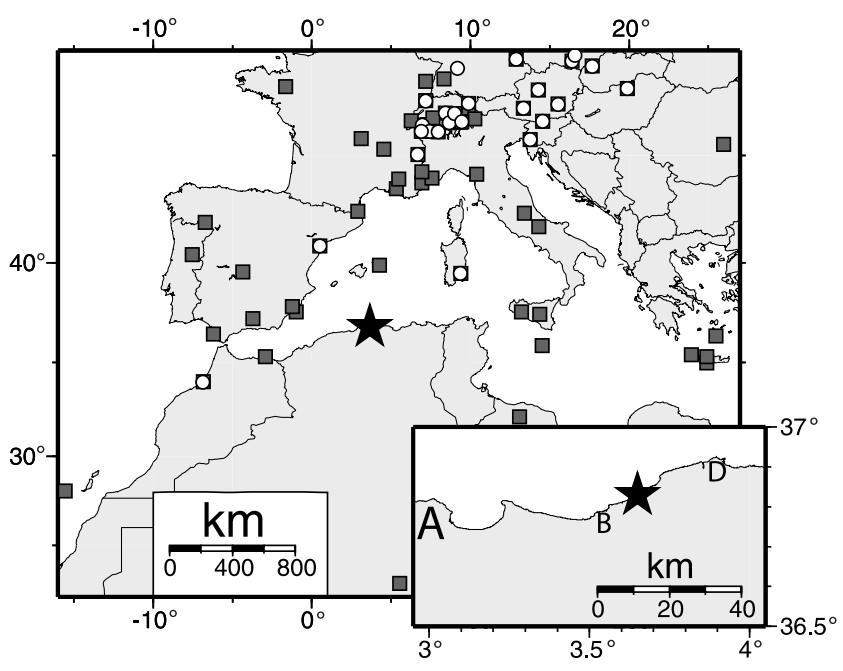

Figure 1. Map of the epicenter region (star) and broadband seismic stations used (squares: off-line, circles: automatic analysis). Stations north of $49.5^{\circ} \mathrm{N}$ are not shown. Not all stations were available for each event. Inset is a close-up; star marks main shock location from Bounif et al. [2004], A: Algiers, B: Boumerdes, D: Dellys.

For small events, we used near-stations and inverted in the 25-40 s, 30-50 s and 33-50 s bands; for large events, we used stations up to $20^{\circ}$ distance and inverted from $40 \mathrm{~s}$ to $60-100 \mathrm{~s}$, the long period cut-off depending on event size. We inverted complete waveforms using PREM synthetics calculated for USGS's PDE locations. Depth was found by grid search with $3-\mathrm{km}$ steps. The method is described in Nábelek and Xia [1995] and European applications are shown in Braunmiller et al. [2002].

[8] We analyzed all $49 \mathrm{M} \geq 4.0$ events of the sequence from May 2003 to January 2004 and obtained $30 \mathrm{M}_{\mathrm{w}} \geq$ 3.8 MT solutions (Table 1 and auxiliary material ${ }^{1}$ ). Thrust mechanisms dominate, though we also found four strikeslip and two normal faulting events. Most events we could not obtain solutions for were immediate main shock aftershocks. Events \#2-19 (Table 1) occurred within the first three days. Their mechanisms could only be obtained with regional waveforms since a temporary network to record aftershocks had not yet been installed [Bounif et al., 2004].

[9] Azimuthal amplitude variations constrain the wellresolved and stable source mechanisms. Figure 2 shows the main shock waveform fit. Thrust fault strike variability and occurrence of strike-slip events are constrained by waveforms at several stations that look distinctly different (Figure 3). Fault rotation from NNE-SSW to E-W follows from amplitude variations of vertical data (e.g., EMV). The vertical-to-transverse amplitude ratio and a $90^{\circ}$ periodicity of near nodal vertical data (DIX, WDD and PAB) constrain strike-slip events. Lack of data from stations south of the epicenter, which precludes constrained first motion solutions, does not cause a resolution problem when three-component waveforms are modeled.

[10] For each event, we estimated strike, dip, and rake bounds for a $5 \%$ variance increase relative to the best

${ }^{1}$ Auxiliary material is available at $\mathrm{ftp}: / / \mathrm{ftp}$.agu.org/apend/gl/ 2004 GL022038. solution by varying one parameter. Main shock bounds for strike, dip and rake are $\pm 6^{\circ}, \pm 5^{\circ}$, and $\pm 6^{\circ}$, respectively; averages for all events are $\pm 13^{\circ}, \pm 9^{\circ}$, and $\pm 14^{\circ}$. Larger events with better coverage and more data have smaller bounds. For dip-slip events, dip is best resolved, and for strike-slip, strike is best resolved. We performed a doublecouple (DC) grid-search for the main shock and strike-slip event \#11 (Table 1) with the smallest DC contribution of all events. The main shock MT is almost a pure DC and the best pure DC is thus nearly identical $\left(64^{\circ} \pm 9^{\circ}, 23^{\circ} \pm 3^{\circ}, 83^{\circ}\right.$ $\left.\pm 11^{\circ}\right)$. For event $\# 11$, differences $\left(17^{\circ} \pm 8^{\circ}, 68^{\circ} \pm 14^{\circ}\right.$, $-22^{\circ} \pm 20^{\circ}$ for moment-tensor DC vs. $11^{\circ} \pm 9^{\circ}, 61^{\circ} \pm 16^{\circ}$, $-24^{\circ} \pm 22^{\circ}$ for best pure DC) are small considering its large non-DC source component. The DC part is well resolved.

[11] Centroid depths (Table 1) are not well constrained because event-station distances are large $(\geq 300 \mathrm{~km})$ and paths cross complex tectonic structures through the Mediterranean Sea before reaching Europe. We thus had to invert at long periods insensitive to small depth variations. Resolved depths are between 6 and $21 \mathrm{~km}$, but including $5 \%$-bounds, most could have occurred from the surface

Table 1. Regional Moment-Tensor Solutions ${ }^{\mathrm{a}}$

\begin{tabular}{|c|c|c|c|c|c|c|c|c|c|}
\hline \# & Date & $\begin{array}{l}\text { Lat } \\
\left({ }^{\circ} \mathrm{N}\right) \\
\end{array}$ & $\begin{array}{l}\text { Lon } \\
\left({ }^{\circ} \mathrm{E}\right)\end{array}$ & $\begin{array}{c}\text { S/D/R } \\
\left({ }^{\circ}\right)\end{array}$ & $\begin{array}{c}\mathrm{P} \\
\left(^{\circ}\right) \\
\end{array}$ & $M_{w}$ & $\begin{array}{c}\text { CD } \\
(\mathrm{km})\end{array}$ & $\begin{array}{l}\mathrm{DC} \\
(\%)\end{array}$ & $\mathrm{CO}$ \\
\hline \multirow[t]{2}{*}{1} & 200305211844 & $36.83^{\mathrm{B}}$ & 3.65 & $62 / 25 / 82$ & 338 & 7.0 & 18 & 76 & 95 \\
\hline & $\mathrm{A}$ & & & & 344 & 6.8 & 10 & 68 & \\
\hline 2 & 200305211851 & $36.813^{\mathrm{R}}$ & 3.702 & $72 / 20 / 82$ & 348 & 5.9 & $18 *$ & 61 & 29 \\
\hline 3 & 305212204 & $36.916^{\mathrm{R}}$ & 3.885 & $76 / 17 / 86$ & 350 & 4.8 & 15 & 74 & 13 \\
\hline 4 & 212318 & & 3.814 & $93 / 23 / 82$ & 9 & 4.7 & $21 *$ & 73 & 50 \\
\hline 5 & 200305212323 & $36.812^{\mathrm{R}}$ & 3.485 & $41 / 21 / 65$ & 331 & 5.1 & 15 & 84 & 67 \\
\hline 6 & 200305220139 & $36.651^{\mathrm{R}}$ & 3.575 & $37 / 21 / 68$ & 324 & 4.3 & $12 *$ & 78 & 37 \\
\hline 7 & 200305220155 & & 3.460 & $69 / 25 / 87$ & 341 & 3.8 & $12 *$ & 100 & 17 \\
\hline \multirow[t]{2}{*}{8} & 200305220314 & $36.822^{\mathrm{R}}$ & 3.626 & $57 / 14 / 78$ & 337 & 5.1 & 9 & 84 & 78 \\
\hline & $\mathrm{A}$ & & & $3 / 43$ & 349 & 5.0 & 10 & 91 & \\
\hline 9 & 200305220429 & $36.891^{\mathrm{R}}$ & 3.565 & $44 / 21 / 96$ & 309 & 3.9 & $12 *$ & 88 & 28 \\
\hline 10 & 2 & & 3.5 & $31 / 24 / 68$ & 318 & 4.3 & 18 & 68 & 47 \\
\hline 11 & 200305220627 & $36.794^{\mathrm{R}}$ & 4.065 & $17 / 68 /-22$ & 337 & 4.8 & $12 *$ & 34 & 67 \\
\hline 12 & 200305221111 & $36.971^{\mathrm{R}}$ & 3.777 & $51 / 16 / 72$ & 336 & 4.6 & 15 & 80 & 47 \\
\hline 13 & 20030 & 36.7 & 3.579 & $9 / 16 / 108$ & 354 & 4.2 & 12 & 35 & 42 \\
\hline \multirow[t]{2}{*}{14} & 200305221357 & $36.833^{\mathrm{R}}$ & 3.934 & $91 / 14 / 101$ & 352 & 5.1 & 12 & 81 & 76 \\
\hline & $\mathrm{A}$ & & & 129 & 355 & 5.1 & 25 & 72 & \\
\hline 15 & 05230008 & $36.822^{\mathrm{R}}$ & 3.720 & $17 / 23 / 71$ & 301 & 4.3 & $9 *$ & 79 & 45 \\
\hline 16 & 20030524031 & 36.8 & 4.050 & $70 / 17 / 77$ & 350 & 4.2 & 15 & 68 & 13 \\
\hline 17 & 200305241551 & $36.888^{\mathrm{R}}$ & 3.650 & $27 / 21 / 61$ & 319 & 4.4 & 15 & 57 & 41 \\
\hline \multirow[t]{2}{*}{18} & 200305241921 & $36.816^{\mathrm{R}}$ & 3.970 & & 350 & 4.8 & 18 & 91 & 52 \\
\hline & $\mathrm{A}$ & & & $25 / 111$ & 349 & 4.7 & 10 & 61 & \\
\hline 19 & 524 & & 3.771 & $20 / 30 / 73$ & 302 & 3.9 & $12 *$ & 99 & 15 \\
\hline \multirow[t]{2}{*}{20} & 200305271711 & $36.783^{\mathrm{R}}$ & 3.610 & $1 / 83$ & 338 & 5.8 & 18 & 84 & 88 \\
\hline & $\mathrm{A}$ & & & & 347 & 5.7 & 10 & 73 & \\
\hline \multirow[t]{2}{*}{21} & 200305280658 & $36.667^{\mathrm{R}}$ & 3.291 & $79 / 18 / 90$ & 346 & 4.9 & 15 & 85 & 76 \\
\hline & $\mathrm{A}$ & & & $78 / 25 / 93$ & 345 & 4.8 & 10 & 85 & \\
\hline & & & 3.436 & $15 / 69 /-39$ & 333 & 4.4 & $9 *$ & 86 & 43 \\
\hline \multirow[t]{2}{*}{23} & 200305290214 & $36.771^{\mathrm{R}}$ & 3.278 & $187 / 87 / 32$ & 317 & 5.0 & 12 & 53 & 82 \\
\hline & $\mathrm{A}$ & & & $188 / 73 / 3$ & 324 & 5.0 & 14 & 73 & \\
\hline & 200306010 & & 4.022 & $101 / 10 /-80$ & & 4.2 & 6 & 69 & 33 \\
\hline 25 & 20030602223 & & 3.369 & $85 / 29 / 93$ & 352 & 4.1 & 12 & 64 & 31 \\
\hline 26 & 200306231035 & $36.923^{\mathrm{R}}$ & 3.712 & $89 / 16 / 94$ & 356 & 4.1 & $12 *$ & 74 & 30 \\
\hline 27 & 200307052003 & & 3.829 & $111 / 20 / 115$ & 2 & 4.1 & 21 & 50 & 34 \\
\hline 28 & 200307060256 & $36.737^{\mathrm{X}}$ & 3.920 & $100 / 16 /-101$ & & 3.9 & $9 *$ & 53 & 54 \\
\hline 29 & 200307142252 & & 3.545 & $65 / 21 / 72$ & 349 & 3.9 & $15^{*}$ & 82 & 9 \\
\hline 30 & 200401101838 & $36.772^{\mathrm{R}}$ & 3.396 & $17 / 63 /-26$ & 339 & 4.7 & $9 *$ & 88 & 39 \\
\hline
\end{tabular}

a\#: event number. Date: year month day hour minute; A: automatic solution. Lat, Lon: latitude, longitude, B: main event location from Bounif et al. [2004], R: relocated, X: shifted. S/D/R: strike, dip, and rake. P: P-axis orientation. $\mathrm{M}_{\mathrm{w}}$ : moment magnitude. $\mathrm{CD}$ : centroid depth; *: constrained. DC: double couple percentage. CO: components (vertical, radial, transverse) used. 


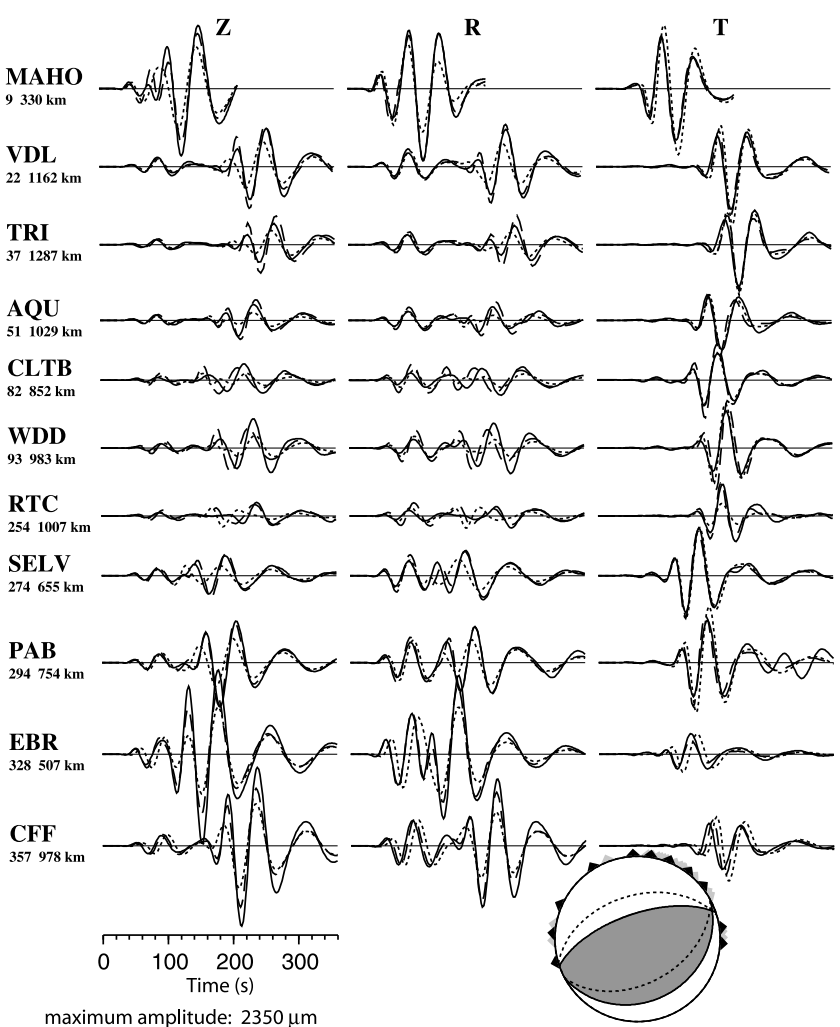

Figure 2. Observed (solid) and synthetic (dashed) main shock waveforms for selected stations in the 40-100 s band. Numbers beneath stations are azimuth and distance. Amplitudes are normalized for cylindrical geometrical spreading. Z, R, and $\mathrm{T}$ are vertical, radial and transverse components. The best solution fault plane solution (lower hemisphere) is shaded; triangles are azimuths (dark for stations shown, light for additional 22 stations used). Dotted lines are fault planes and synthetics for a $45^{\circ}$-dipping source (instead of $25^{\circ}$, with strike $=62^{\circ}$ and rake $=82^{\circ}$ fixed).

down to $20-25 \mathrm{~km}$ depth. Our main shock centroid (18 \pm $5 \mathrm{~km}$ ) is slightly deeper than its hypocenter estimate of 8 $10 \mathrm{~km}$ [Bounif et al., 2004]. Generally, our depths are compatible with aftershock depths from 4 to $16 \mathrm{~km}$ [Bounif et al., 2004] but are not precise enough to resolve spatial depth variations within the shallow sequence.

\section{Teleseismic Relocation}

[12] Deriving a simple rupture model requires accurate relative locations. We thus relocated all earthquakes with a moment tensor solution relative to the main shock epicenter [Bounif et al., 2004]. We applied the joint epicenter determination technique [Douglas, 1967] to teleseimic P-wave arrival times. All depths were constrained to $10 \mathrm{~km}$ due to limited resolution of teleseismic data. We consider 25 events with longitudinal uncertainties of less than $\pm 6 \mathrm{~km}$ at the 95\%-confidence limit well relocated. Five events were shifted from their PDE location by $-0.134^{\circ}$ latitude and $0.016^{\circ}$ in longitude, the difference between the PDE and Bounif et al. [2004] main shock locations. Relocations are marked ' $R$ ' and shifts ' $\mathrm{X}$ ' in Table 1. The east-west epicenter extent is well constrained by the station distribution mainly towards north; latitudinal uncertainties are almost a factor 2 larger. Figure 4 shows fault plane solutions on their relocated, respectively, shifted epicenters.

\section{Discussion and Conclusion}

[13] The main shock thrust event generated a vigorous aftershock sequence with diverse focal mechanisms (Figure 4) indicating activity along several faults and fault segments. For the first three days, all events (\#1-19) except strike-slip event \#11 were thrusts. After the large aftershock $\# 20$, mechanisms were more diverse and we found thrust, strike-slip and even normal faulting. Activity west of $3.45^{\circ} \mathrm{E}$ $(\# 21,22,23,25,30)$ started only then. The largest aftershocks $(\# 2,8,20)$ occurred very close to and had very similar mechanisms as the main shock. This 'main shock cluster' (including $\# 5,12,13$ ) has a median $338^{\circ}$ P-axes orientation. Thrust events east of about $3.8^{\circ} \mathrm{E}(\# 3,4,14,16$, 18 , also 26) have a slightly more northerly $352^{\circ}$ median, which could indicate a $10^{\circ}-15^{\circ}$ fault bend that coincides with a coastline bend near $3.9^{\circ} \mathrm{E}$. The more northerly oriented thrusts $(\# 6,9,10,15,17,19)$ occurred also close to the main shock. Their latitudinal uncertainties allow that all could have occurred near $36.8^{\circ} \mathrm{N}$ and $3.5^{\circ}-3.7^{\circ} \mathrm{E}$ where Bounif et al. [2004] found a tight aftershock cluster. We assume these events occurred in the hanging wall where the normal events \#24, 28, the southern thrusts \#7,29, 27 and strike-slip event \#11 probably also occurred.

[14] The strike-slip events \#22, 23, and 30 probably define a north-south trending left-lateral transform fault that stopped main shock rupture from propagating further west.

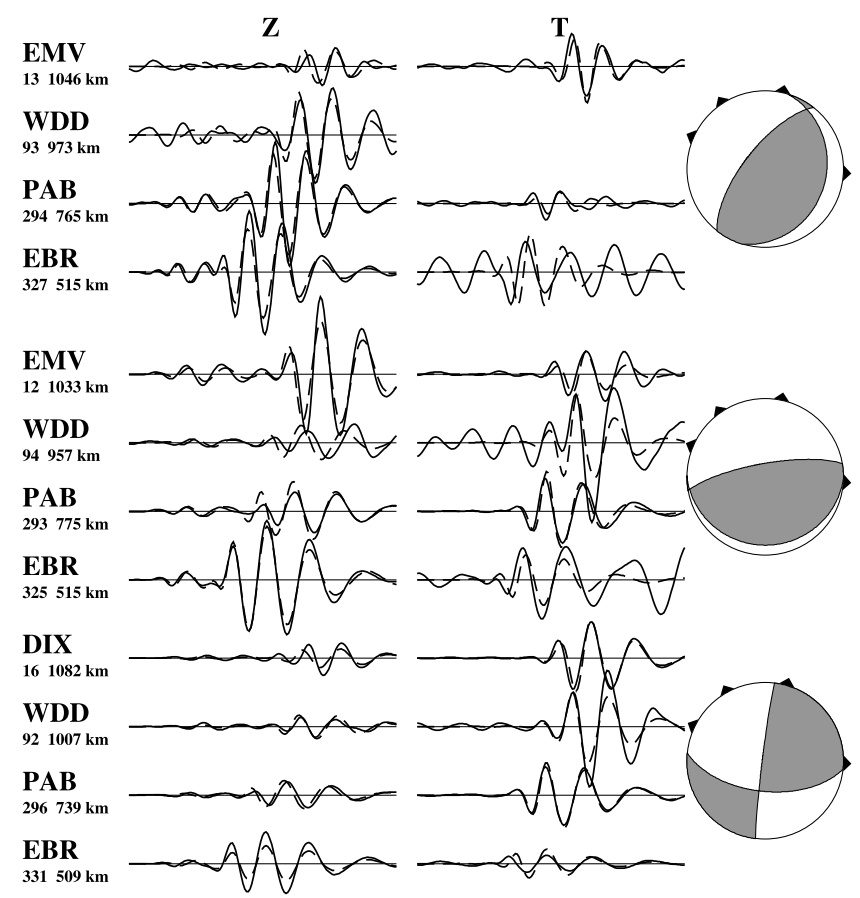

Figure 3. Observed (solid) and synthetic (dashed) waveforms for thrust and strike-slip events for selected stations. Seismograms are $300 \mathrm{~s}$ long. Shown are, top to bottom, events \#15, 14, 23 (Table 1). WDD (Malta), PAB and EBR (both Spain) are shown for all events; WDD horizontals for \#15 were noisy. EMV and DIX in Switzerland have nearly identical distance and azimuth. For details see Figure 2. 


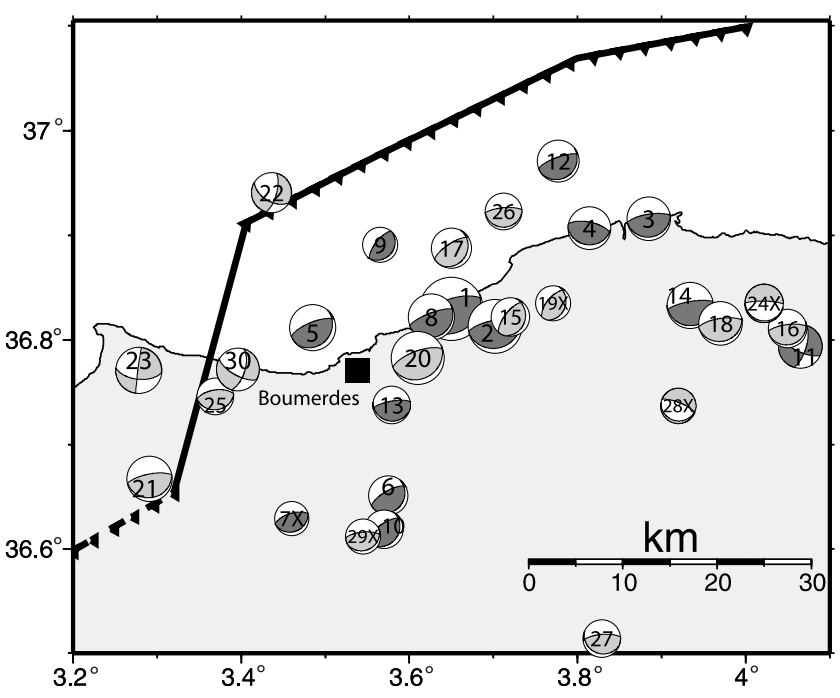

Figure 4. Fault plane solutions of events studied, size proportional to $\mathrm{M}_{\mathrm{w}}$. Dark: first day, light: later events. Event numbers are as in Table 1. Shifted events are marked ' $\mathrm{X}$ '; others are relocated. Heavy lines show our interpretation of faults activated based on main shock hypocenter and dip, first day aftershocks (events \#2-\#14), strike-slip event distribution (\#22, 23, 30) and P-axes rotation of eastern thrusts relative to main shock; dashed line in southwest corner is a possible thrust extension in the Mitidja basin not active during this sequence.

The location of the postulated transform coincides with the western aftershock end [Bounif et al., 2004], rupture termination from horizontal GPS data [Yelles et al., 2004], and lack of coastal uplift west of $3.4^{\circ} \mathrm{E}$ [Meghraoui et al., 2004]. The transform forms a step-over of main thrust faulting, which further west might be accommodated along the Blida thrust system at the southern border of Mitidja basin [Bounif et al., 2004; Meghraoui et al., 2004].

[15] Fault dip is the best-constrained parameter for thrust events. The south dipping plane of the main shock and of all thrust events dips with less than $30^{\circ}$. Regional waveforms are incompatible with steeper dips (Figure 2) found by teleseismic body wave inversions, Delouis et al. [2004] obtain $40^{\circ}$, Harvard and USGS have $44^{\circ}$ and $47^{\circ}$. A shallow main thrust dip agrees with an aftershock cross-section in Bounif et al. [2004] dipping shallowly to the SSE. Though Bounif et al. [2004] suggest the main thrust plane cuts steeply through the aftershocks it seems more likely that the aftershocks cluster either around or just above the main thrust. Combining our fault dip $\left(25^{\circ} \pm 5^{\circ}\right)$ with location $\left(36.83^{\circ} \mathrm{N}, 3.65^{\circ} \mathrm{E}\right)$ and depth $(8-10 \mathrm{~km})$ from Bounif et al. [2004] results in a fault surface emergence $15-20 \mathrm{~km}$ offshore (assuming $\sim 2 \mathrm{~km}$ deep water). A morpho-tectonic map that shows active scarps at the bottom and mid-slope of the continental shelf parallel to the coast $\sim 17 \mathrm{~km}$ offshore [Déverchere et al., 2003] agrees with our model.

[16] We estimate a main shock rupture length of about $50 \mathrm{~km}$ based on the intersection of the proposed transform with the main thrust and the first day aftershocks, which extend to about $3.9^{\circ} \mathrm{E}(\# 14)$. The estimate agrees with modeling of coastal uplift [Meghraoui et al., 2004] and of seismic and GPS data [Delouis et al., 2004; Semmane et al., 2005; Yelles et al., 2004]. Assuming rupture initiated at $10 \mathrm{~km}$ depth and propagated to the sea bottom along a $25^{\circ}$ dipping $50 \mathrm{~km}$-long fault gives an average fault displacement of about $1 \mathrm{~m}$ (rigidity $3 \times 10^{10} \mathrm{~N} / \mathrm{m}^{2}$ ) consistent with slip-models [Delouis et al., 2004; Semmane et al., 2005].

[17] The Boumerdes earthquake sequence was caused by Africa-Eurasia convergence. The local $330^{\circ}$ relative motion direction [DeMets et al., 1994] agrees with the $338^{\circ}$ median $\mathrm{P}$-axis orientation of thrust and strike-slip events. The region experienced few earthquakes prior to 2003 and seismic hazard was considered relatively low [YellesChaouche et al., 2003]. However, plate motions are essentially the same along entire northern Africa and destructive earthquakes could occur anywhere along the margin (like the $\mathrm{M}_{\mathrm{w}}=6.4$ event near El Hoceima, Morocco in February 2004).

[18] Acknowledgments. We thank the Geofon, Geoscope, IRIS, MedNet, Nice University, ORFEUS, ReNass, Swiss SDS-Net, SZGRF, and ZAMG data centers for high-quality waveform data, A. Douglas for the JED code, and the USGS and ISC for phase data.

\section{References}

Ayadi, A., et al. (2003), Strong Algerian earthquake strikes near capital city, Eos Trans. AGU, 84(50), 561-568.

Bernardi, F., J. Braunmiller, U. Kradolfer, and D. Giardini (2004), Automatic regional moment tensor inversion in the European-Mediterranean region, Geophys. J. Int., 157, 703-716.

Bounif, A., et al. (2004), The 21 May 2003 Zemmouri (Algeria) earthquake $\mathrm{M}_{\mathrm{w}}$ 6.8: Relocation and aftershock sequence analysis, Geophys. Res. Lett., 31, L19606, doi:10.1029/2004GL020586.

Braunmiller, J., U. Kradolfer, M. Baer, and D. Giardini (2002), Regional moment tensor inversion in the European-Mediterranean region-Initial results, Tectonophysics, 356, 5-22.

Delouis, B., et al. (2004), Slip distribution of the 2003 Boumerdes-Zemmouri earthquake, Algeria, from teleseismic, GPS, and coastal uplift data, Geophys. Res. Lett., 31, L18607, doi:10.1029/2004GL020687.

DeMets, C., R. G. Gordon, D. F. Argus, and S. Stein (1994), Effect of recent revisions to the geomagnetic reversal timescale on estimates of current plate motions, Geophys. Res. Lett., 21, 2191-2194.

Déverchere, J., K. Yelles, and E. Calais (2003), Active deformation along the Algerian Margin (Maradja cruise): Framework of the May 21, 2003, $\mathrm{M}_{\mathrm{w}}-6.8$ Boumerdes earthquake, Eos Trans. $A G U, 84(47)$, Fall Meet. Suppl., Abstract S42E-0216.

Douglas, A. (1967), Joint epicentre determination, Nature, 215, 47-48.

Hébert, H., and P.-J. Alasset (2003), The tsunami triggered by the 21 May 2003 Algiers earthquake, CSEM/EMSC Newsl., 20, 10-12.

Meghraoui, M., A. Cisternas, and H. Philip (1986), Seismotectonics of the lower Cheliff basin: Structural background of the El Asnam (Algeria) earthquake, Tectonics, 5, 809-836.

Meghraoui, M., et al. (2004), Coastal uplift and thrust faulting associated with the $\mathrm{Mw}=6.8$ Zemmouri (Algeria) earthquake of 21 May, 2003, Geophys. Res. Lett., 31, L19605, doi:10.1029/2004GL020466.

Nábelek, J., and G. Xia (1995), Moment-tensor analysis using regional data: Application to the March 25, 1993, Scotts Mills, Oregon, earthquake, Geophys. Res. Lett., 22, 13-16.

Semmane, F., M. Campillo, and F. Cotton (2005), Fault location and source process of the Boumerdes, Algeria, earthquake inferred from geodetic and strong motion data, Geophys. Res. Lett., 32, L01305, doi:10.1029/ 2004GL021268.

Yelles-Chaouche, A. K., H. Djellit, and M. Hamdache (2003), The Boumerdes-Algiers (Algeria) earthquake of May 21st, $2003\left(\mathrm{M}_{\mathrm{w}}=6.8\right)$, CSEM/EMSC Newsl., 20, 3-5.

Yelles, K., K. Lammali, A. Mahsas, E. Calais, and P. Briole (2004), Coseismic deformation of the May 21st, 2003, $\mathrm{M}_{\mathrm{w}}=6.8$ Boumerdes earthquake, Algeria, from GPS measurements, Geophys. Res. Lett., 31, L13610, doi:10.1029/2004GL019884.

F. Bernardi and J. Braunmiller, Swiss Seismological Service, Institute of Geophysics, Eidgenössische Technische Hochschule Zürich, CH-8093 Zurich, Switzerland. (jochen@sed.ethz.ch) 